\title{
THE EFFECT OF CONTENT INSTRUCTION IN L2 ON L1 PRAGMATICS
}

\author{
MEHMET KANIK
}

The University of Houston

mehmetkanik@gmail.com

\begin{abstract}
This study investigates whether content instruction in English has an impact on L1 pragmatics. In this study a discourse completion test with eight request situations in Turkish was given to three groups of Turkish students enrolled in undergraduate programs in a faculty of education in Turkey. One group of students received most of their education in English. The other two groups received their education in Turkish. An interesting finding is that the differences in the make-up of the situations were only observed in situations with high imposition. This shows that instruction in the foreign language has an impact on sociopragmatic interpretation in L1. Overall, the results reveal that instruction in foreign language has an impact on first language pragmatic use.
\end{abstract}

Key words: Language transfer, cross-linguistic influence, pragmatic transfer, L2 effect

\section{Introduction}

"English as a Lingua Franca" (Seidlhofer, 2005: 339) is a term that has emerged to refer to communication among people who do not share a native language. A necessity for this term possibly emerged because of the global spread of English and the resulting millions of people worldwide who do not speak it as a mother tongue. In fact, the spread today has reached a point where the speakers of English as a second or foreign language outnumber native speakers drastically. According to approximations made by Graddol (2000) and Crystal (1997) there are about one and a half billion speakers of English in the world and only one forth of them speak English as a mother tongue. Among the rest, one forth are the speakers of English as a second language in postcolonial regions such as India and Nigeria. The remaining half of English speakers speak it as a foreign language. Moreover, this gap is continuously expanding. With this picture in mind, it would not be wrong to argue that most exchanges in English in the world take place between speakers of English who do not share a common language other than English. This type of conversations, without the presence of native speakers and ESL speakers, or English as a Lingua Franca, accounts for the most common exchanges globally. Today, English is everywhere we look. It is the language of international education, business, transportation, publication, media, and internet. This widespread function of English results in global learning of English. Today, English is introduced at the primary stages of formal schooling in Turkey. For example, in Turkish state schools, English is 
introduced in fourth grade. In the private sector, it can be introduced as early as kindergarten. Another effect of the global function of English is offering Englishmedium programs in English at universities where neither the lecturers nor the students are native English speakers. According to a survey conducted in 1,558 higher education institutes in 19 non-English speaking countries in Europe in 2001/2002, 30\% of the programs were in English (Maiworm \& Wächter, 2002; cited in Coleman, 2006: 6). Airey (2004) says the general reasons behind this is "internationalization, preparing students for an academic world dominated by English and competitive advantages on the job market”. He (Airey, 2003: 47: in Airey, 2004) also lists seven advantages of offering programs in English:

1. In a number of disciplines, the publication of academic papers takes place almost exclusively in English. Teaching in English is therefore seen as necessary in order to prepare students for an academic career.

2. In many disciplines the majority of textbooks used are written in English and therefore the step to teaching in English may not be seen as a large one.

3. The use of English develops the language skills and confidence of Swedish lecturers and can be seen as promoting movement/exchange of ideas in the academic world.

4. Using English as the language of instruction allows the use of visiting researchers in undergraduate and postgraduate teaching.

5. Teaching in English allows exchange students to follow courses at Swedish universities.

6. Swedish students can be prepared for their own studies abroad.

7. A sound knowledge of English has become a strong asset in the job market.

He also lists the concerns about offering programs in English as domain losses to English, possible future diglossia and the quality of content. Although he is concerned with Swedish higher education, this issue is global. Another concern should be raised about this issue. Opening programs in English could bring in the advantages listed above. However, the possibility of its affecting the native language of the learners should be a strong concern.

The influence of a language on another is not a new phenomenon. It has been acknowledged for several decades now. Fore example, Lado (1957: 2) says:

Individuals tend to transfer the forms and meanings, and the distribution of forms and meanings of their native language and culture to the foreign language and culture - both productively when attempting to speak the language and to act in the culture, and respectively when attempting to grasp and understand the language and the culture as practiced by natives.

Selinker (1972) proposed the view that by transferring from their native language, learners create an interlanguage that is different from both the native and the target language. This transfer has often been referred to as language transfer and crosslinguistic influence. These terms have been used to mean the effect of the first language on the second language (Pavlenko \& Jarvis, 2002: 190) sometimes as an imposition (Gass, 1979: 328) while at other times as a coping strategy with the new 
challenges in learning a second language (Jarvis \& Odlin, 2000: 537). Although language tranfer is not a new phenomenon, the reverse case, that is the effect of the second language on the first, has not received enough attention until recently (Pavlenko \& Jarvis, 2002: 191). In recent years, some scholars acknowledge the possibility of the effect of the second language on the first. Scott and Odlin (2000: 537), for instance, say "cross-linguistic influence can also work in the opposite direction, where the acquisition of L2 structures causes some kind of change in the L1." Kecskes and Papp (2003: 251) also assert that transfer refers to movements in either direction between the first and second language. Pavlenko and Jarvis (2002: 190) refer to this movement in either direction as the concept of bidirectionality. Different scholars have proposed different theories regarding the movement between languages in the mind of an L2 user. For example, Cook (2003: 2, citing Cook, 1991) claims that while learning additional languages, learners develop multi-competence, a term used to refer to the 'knowledge of two or more languages in one mind'. Jarvis (2003: 82) also explains this phenomenon with a multi-competence framework. On the other hand, Kecskes \& Papp (2003: 249252) approach this phenomenon in terms of conceptual transfer. As the learner continues further along the learning of a second language, concepts of the second language is transferred to the first language and the vice versa and eventually a Common Underlying Conceptual Base emerges in the mind of the L2 learner. They also claim that while low proficient learners transfer linguistic elements from L1, high proficient learners start to make conceptual transfer between the languages they know and they develop CUCB that is distinct from both $\mathrm{L} 1$ and $\mathrm{L} 2$.

In the area of pragmatics, most studies and papers concerning transfer has reflected on transfer from one's native language to the target language. Among the languages and the direction of effect researched are from Arabic L1 to English L2 (Al-Eryani, 2007), Chinese L1 to English L2 (Chang, 2009; Jia, 2007; Qu \& Wang, 2005; Rose, 2000), from English L1 to Indonesian L2 (Hassall, 2003), from 10 different L1s to English L2 (Kecskes, 2000), from Japanese L1 to English L2 (Sasaki \& Beamer, 2002), from Vietnamese L1 to English L2 (Tran, 2007), and from Thai L1 to English L2 (Wannaruk, 2008). On the other hand, only a few studies investigated the opposite case, namely pragmatic transfer from the second language to the first (e.g. Blum-Kulka and Shaffer, 1993; Cenoz, 2003; Silva, 2000). This study deals with this latter type of pragmatic transfer by investigating whether content instruction in L2 has an impact on L1 pragmatics.

\section{Methods}

The data was collected using a discourse completion test. Initially eight request situations in Turkish were created based on three sociopragmatic variables of relative power of speaker to hearer, distance between speaker and hearer and the absolute ranking of imposition (Brown and Levinson, 1987; Hudson, Detmer and Brown, 1995). The variables distribute to eight situations based on their being rated either high or low. Neutral rankings were not used. 


\begin{tabular}{|c|c|c|c|}
\hline & Speaker & Hearer & Request \\
\hline Situation 1 & $\begin{array}{l}\text { A human } \\
\text { resources } \\
\text { manager }\end{array}$ & $\begin{array}{l}\text { An applicant } \\
\text { from another city }\end{array}$ & $\begin{array}{l}\text { Come again } \\
\text { next week for } \\
\text { a second } \\
\text { interview }\end{array}$ \\
\hline Situation 2 & A customer & $\begin{array}{l}\text { A sales } \\
\text { representative }\end{array}$ & $\begin{array}{l}\text { Take out a } \\
\text { watch from a } \\
\text { display case }\end{array}$ \\
\hline Situation 3 & $\begin{array}{l}\text { A manager in a } \\
\text { factory }\end{array}$ & A worker & Work overtime \\
\hline Situation 4 & $\begin{array}{l}\text { A school } \\
\text { principal }\end{array}$ & A teacher & $\begin{array}{l}\text { Submit } \\
\text { grading roster }\end{array}$ \\
\hline Situation 5 & $\begin{array}{l}\text { An employee in a } \\
\text { restaurant }\end{array}$ & $\begin{array}{l}\text { A customer who } \\
\text { reserved a table }\end{array}$ & $\begin{array}{l}\text { Move to } \\
\text { another table }\end{array}$ \\
\hline Situation 6 & $\begin{array}{l}\text { A sales } \\
\text { representative }\end{array}$ & A customer & Move aside \\
\hline Situation 7 & A college student & A professor & $\begin{array}{l}\text { Extend } \\
\text { deadline for a } \\
\text { project }\end{array}$ \\
\hline Situation 8 & An employee & $\begin{array}{l}\text { A department } \\
\text { administrator }\end{array}$ & $\begin{array}{l}\text { Give another } \\
\text { form for } \\
\text { annual leave }\end{array}$ \\
\hline
\end{tabular}

Table 1: Situations

The eight situations created were given to 10 educated native speakers of Turkish to rate the sociopragmatic variables so that the researcher could see the situations reflect the intended sociopragmatic design. Next, necessary modifications were made to two situations that seemed to be interpreted differently than the researcher intended. The revised situations were rated again by the native speakers. Upon completion, 10 other native speakers took the test by providing requests appropriate in each situation. The aim of this process was to see whether the situations were able to elicit requests. Then, the test was given to 107 native Turkish speaking seniors at four undergraduate degree programs at a faculty of education in Istanbul, Turkey. Forty of them were males and 67 of them were females. Moreover, 42 of them were in English language teaching (ELT) program, receiving 67\% of their content education in English throughout their education. The students in the other three programs, namely, Turkish language teaching (TLT), social science teaching (SST) and primary school teaching (PST), received their education in Turkish except for two two-unit mandatory English courses. The students in 
these programs were randomly divided into two groups to see if random differences occur between these students' language use. Group 1 is composed of the students from ELT program who received their education mostly in English and group 2 and 3 refer to the students from three programs who received their education in Turkish. Tables 2 through 4 show participants' profiles.

\begin{tabular}{lllllll}
\hline \hline & & \multicolumn{2}{l}{ Program } & & & \\
\cline { 2 - 6 } & & ELT & TLT & SST & PST & Total \\
\hline \multirow{2}{*}{ Gender } & 1 & 19 & 8 & 10 & 3 & 40 \\
& 2 & 23 & 12 & 15 & 17 & 67 \\
\multirow{2}{*}{ Total } & 42 & 20 & 25 & 20 & 107 \\
\hline \hline
\end{tabular}

Table 2: Participant profile by degree program

\begin{tabular}{lccccc}
\hline \hline & \multicolumn{3}{c}{ Group } & \multicolumn{2}{c}{ Total } \\
\cline { 2 - 5 } & 1 & 2 & 3 & \\
\hline \multirow{2}{*}{ Gender 1} & 19 & 11 & 10 & 40 \\
\cline { 2 - 5 } Total & 2 & 23 & 22 & 22 & 67 \\
\cline { 2 - 5 } & 42 & 33 & 32 & 107 \\
\hline \hline
\end{tabular}

Table 3: Participant profile by groups

\begin{tabular}{lllll}
\hline Group & Mean & $\mathrm{N}$ & \multicolumn{2}{l}{ Min. Max. } \\
\hline 1 & 22,55 & 42 & 21 & 25 \\
\cline { 2 - 5 } 2 & 22,70 & 33 & 21 & 26 \\
\cline { 2 - 5 } 3 & 22,84 & 32 & 20 & 30 \\
\cline { 2 - 5 } Total & 22,68 & 106 & 20 & 30 \\
\hline
\end{tabular}

Table 4: Age of participants by groups

At the end, the requests from three groups were coded into request based on the coding manuals in Blum-Kulka, House and Kasper (1989) and Hudson, Detmer and Brown (1995). Length of requests and the number of strategies used were also coded. Head acts, supportive moves and downgraders were analyzed with the chi-square test. Moreover, length of requests and the number of strategies were analyzed with ANOVA. 


\section{Results}

Results are presented below in tables 4 through 13. Chi-square values for head acts, supportive moves and downgraders are presented in tables 5 through 7 . Next, in tables 8 through 14, the results from the ANOVA for the lengths of requests and the numbers of strategies in groups of head act, supportive moves and downgraders are presented. When significant differences are evident, ANOVA tables are followed by post-hoc tests to see the source of difference.

\begin{tabular}{llll}
\hline \hline Situations & Chi-square & Df & Sig. \\
\hline Situation 1 & 17,926 & 14 &, 210 \\
\hline Situation 2 & 4,099 & 6 &, 663 \\
\hline Situation 3 & 19,445 & 16 &, 246 \\
\hline Situation 4 & 21,939 & 12 &, $038^{*}$ \\
\hline Situation 5 & 14,639 & 16 &, 551 \\
\hline Situation 6 & 11,142 & 12 &, 517 \\
\hline Situation 7 & 20,035 & 14 &, 129 \\
\hline Situation 8 & 9,759 & 10 &, 462 \\
\hline
\end{tabular}

Table 5: Chi-square values for head acts

Table 5 shows provide the results of chi-square test for head acts. As table shows, there is a significant difference between the groups only in situation 4. In all other seven situations, the strategies in the head act used by the groups used distribute similarly.

\begin{tabular}{llll}
\hline \hline Situations & Chi-square & Df & Sig. \\
\hline Situation 1 & 9,231 & 14 &, 816 \\
\hline Situation 2 & 15,253 & 12 &, 228 \\
\hline Situation 3 & 11,844 & 16 &, 755 \\
\hline Situation 4 & 7,117 & 10 &, 714 \\
\hline Situation 5 & 10,422 & 16 &, 844 \\
\hline Situation 6 & 10,630 & 12 &, 561 \\
\hline
\end{tabular}




\begin{tabular}{llll}
\hline \hline Situations & Chi-square & Df & Sig. \\
\hline Situation 7 & 22,042 & 20 &, 338 \\
\hline Situation 8 & 6,345 & 8 &, 609 \\
\hline
\end{tabular}

Table 6: Chi-square values for supportive moves

Table 6 shows that the groups did not differ significantly in any of the situations in terms of the strategies in the category of supportive moves.

\begin{tabular}{llll}
\hline \hline Situations & Chi-square & Df & Sig. \\
\hline Situation 1 & 19,638 & 18 &, 354 \\
\hline Situation 2 & 6,235 & 14 &, 960 \\
\hline Situation 3 & 11,442 & 20 &, 934 \\
\hline Situation 4 & 15,825 & 16 &, 465 \\
\hline Situation 5 & 17,242 & 20 &, 637 \\
\hline Situation 6 & 11,095 & 14 &, 679 \\
\hline Situation 7 & 31,701 & 18 &, $024^{*}$ \\
\hline Situation 8 & 31,779 & 20 &, $046^{*}$ \\
\hline
\end{tabular}

Table 7: Chi-square values for downgraders

Table 7 shows that there are significant differences between the groups in situation 7 and 8 in terms of the strategies used in the category of downgraders. The groups did not show differences in situations 1 through 6 .

\begin{tabular}{|c|c|c|c|c|}
\hline & \multicolumn{2}{|c|}{ Sum of Squares df } & \multicolumn{2}{|c|}{ Mean Square F } \\
\hline s1Length Between Groups & 479,027 & 2 & 239,514 & $4,293 *, 016$ \\
\hline Within Groups & 5802,169 & \multicolumn{3}{|c|}{10455,790} \\
\hline Total & 6281,196 & \multicolumn{3}{|c|}{106} \\
\hline \multicolumn{2}{|c|}{ s2Length Between Groups 63,723 } & & 31,862 & $1,264,287$ \\
\hline Within Groups & 2620,632 & & 25,198 & \\
\hline
\end{tabular}




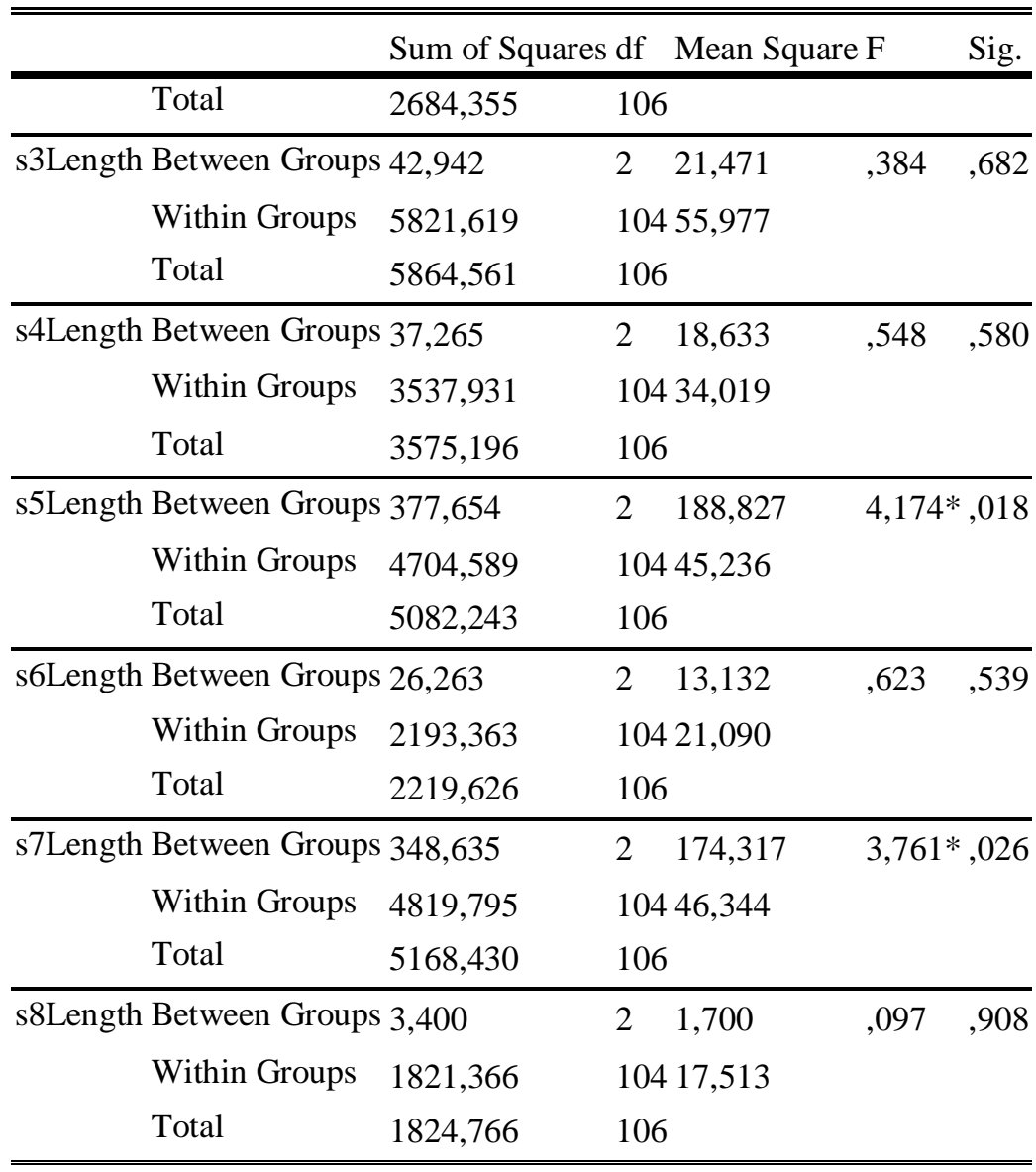

Table 8: ANOVA values for lengths of requests

According to table 8, the length of requests the groups used was significantly different in situation 1, 5 and 7 . In the rest of the situations, the groups' requests were similar in length.

\begin{tabular}{llllll}
\hline \hline $\begin{array}{c}\text { Dependent } \\
\text { Variable }\end{array}$ & $\begin{array}{c}\text { (I) } \\
\text { Grup }\end{array}$ & $(\mathrm{J})$ Grup & $\begin{array}{c}\text { Mean } \\
\text { Difference (I-J) }\end{array}$ & Std. Error & Sig. \\
\hline s1Length & 1 & 2 & $4,680^{*}$ & 1,738 &, 022 \\
& & 3 & 3,879 & 1,753 &, 074 \\
\hline
\end{tabular}




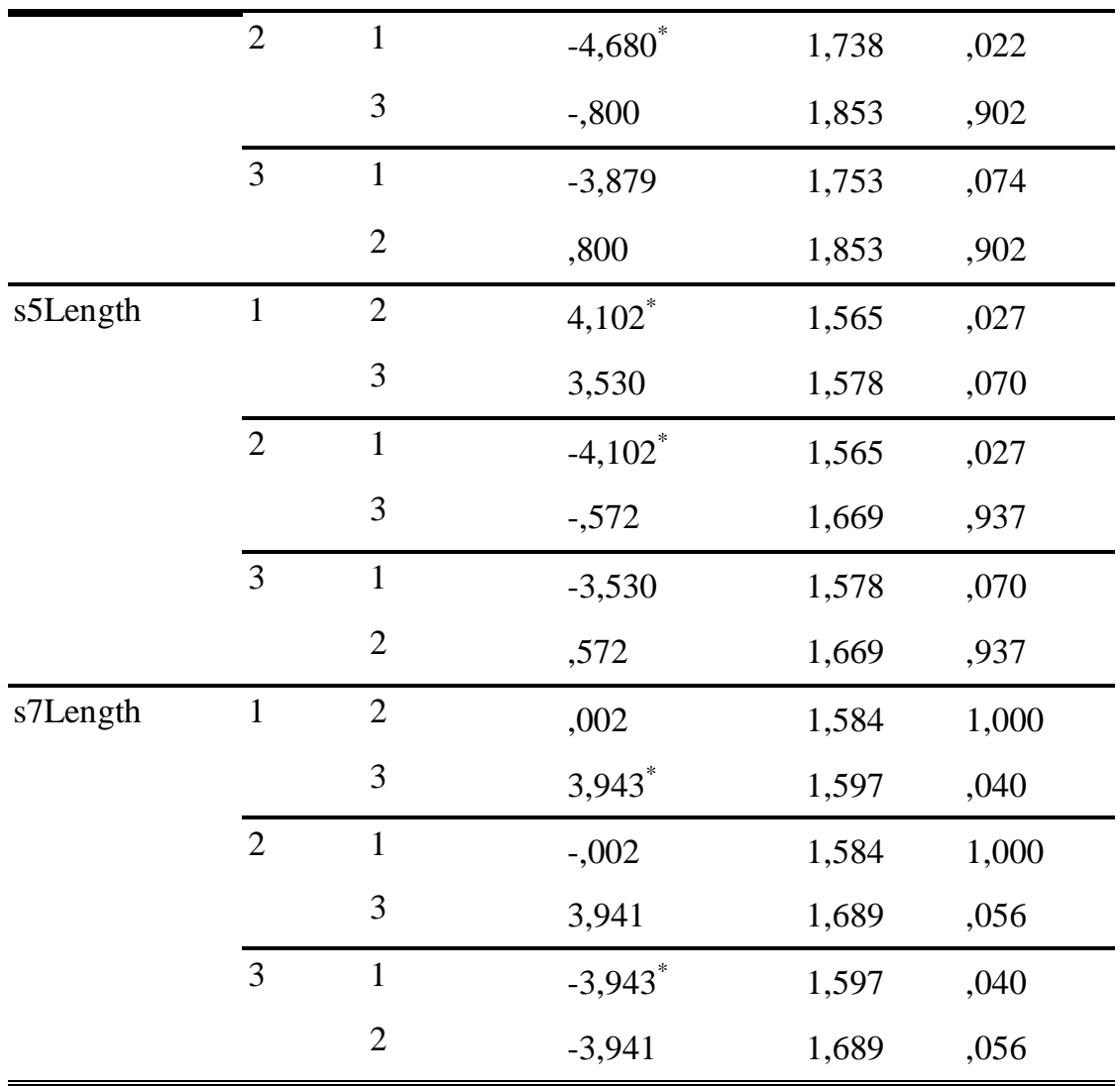

*. The mean difference is significant at the 0.05 level.

Table 9: Post-hoc tests for lengths of requests

Table 9 shows the post-hoc test results for the length of requests. In situation 1, the length of requests provided by group 1 was greater than group 2 and there was no difference between group 2 and 3. Similarly in situation 5, group two used longer requests than group 2 and there was no difference between group 2 and three. In situation 7, the length of requests of group 1 was greater than group 3 and there was no difference between group 2 and three.

\begin{tabular}{|c|c|c|c|c|c|c|}
\hline & & Sum of Squares & df & Mean Square & F & Sig. \\
\hline \multirow{2}{*}{ s1NumHA } & Between Groups & ,067 & 2 &, 034 &, 427 & ,654 \\
\hline & Within Groups & 8,176 & 104 & 079 & & \\
\hline
\end{tabular}




\begin{tabular}{|c|c|c|c|c|c|}
\hline & & Sum of Squares & df 1 & an Square & F Sig. \\
\hline & Total & 8,243 & 106 & & \\
\hline \multirow{3}{*}{ s2NumHA } & Between Groups & ,290 & 2 &, 145 & $2,807,065$ \\
\hline & Within Groups & 5,374 & 104 &, 052 & \\
\hline & Total & 5,664 & 106 & & \\
\hline \multirow{3}{*}{ s3NumHA } & Between Groups &, 154 & 2 &, 077 & 992, 374 \\
\hline & Within Groups & 8,089 & 104 &, 078 & \\
\hline & Total & 8,243 & 106 & & \\
\hline \multirow{3}{*}{ s4NumHA } & Between Groups &, 030 & 2 &, 015 & 280,757 \\
\hline & Within Groups & 5,633 & 104 &, 054 & \\
\hline & Total & 5,664 & 106 & & \\
\hline \multirow{3}{*}{ s5NumHA } & Between Groups &, 116 & 2 &, 058 & $2,102,127$ \\
\hline & Within Groups & 2,874 & 104 & ,028 & \\
\hline & Total & 2,991 & 106 & & \\
\hline \multirow{3}{*}{ s6NumHA } & Between Groups &, 014 & 2 & ,007 & ,770, 465 \\
\hline & Within Groups & ,976 & 104 & ,009 & \\
\hline & Total & ,991 & 106 & & \\
\hline \multirow{3}{*}{ s7NumHA } & Between Groups & ,102 & 2 &, 051 & $1,134,326$ \\
\hline & Within Groups & 4,665 & 104 &, 045 & \\
\hline & Total & 4,766 & 106 & & \\
\hline \multirow{3}{*}{ s8NumHA } & Between Groups &, 000 & 2 &, 000 & . \\
\hline & Within Groups &, 000 & 104 &, 000 & \\
\hline & Total & 000 & 106 & & \\
\hline
\end{tabular}

Table 10: ANOVA for number of head acts

Table 10 shows the result of ANOVA for the number of head acts. As requests, by nature, are single-headed speech acts, there is no significant difference between the groups in the number of strategies they employed. 


\begin{tabular}{|c|c|c|c|c|c|c|}
\hline & & $\begin{array}{l}\text { Sum of } \\
\text { Squares }\end{array}$ & df & $\begin{array}{l}\text { Mean } \\
\text { Square }\end{array}$ & $\mathrm{F}$ & Sig. \\
\hline \multirow[t]{3}{*}{ s1NumSup } & $\begin{array}{l}\text { Between } \\
\text { Groups }\end{array}$ & ,889 & 2 & ,444 & ,627 &, 536 \\
\hline & $\begin{array}{l}\text { Within } \\
\text { Groups }\end{array}$ & 73,672 & 104 & ,708 & & \\
\hline & Total & 74,561 & 106 & & & \\
\hline \multirow[t]{3}{*}{ s2NumSup } & $\begin{array}{l}\text { Between } \\
\text { Groups }\end{array}$ & 2,358 & 2 & 1,179 & 2,453 & ,091 \\
\hline & $\begin{array}{l}\text { Within } \\
\text { Groups }\end{array}$ & 49,997 & 104 & ,481 & & \\
\hline & Total & 52,355 & 106 & & & \\
\hline \multirow[t]{3}{*}{ s3NumSup } & $\begin{array}{l}\text { Between } \\
\text { Groups }\end{array}$ &, 210 & 2 &, 105 &, 280 & ,756 \\
\hline & $\begin{array}{l}\text { Within } \\
\text { Groups }\end{array}$ & 38,949 & 104 & ,375 & & \\
\hline & Total & 39,159 & 106 & & & \\
\hline \multirow[t]{3}{*}{ s4NumSup } & $\begin{array}{l}\text { Between } \\
\text { Groups }\end{array}$ & 1,865 & 2 & ,932 & 2,320 &, 103 \\
\hline & $\begin{array}{l}\text { Within } \\
\text { Groups }\end{array}$ & 41,799 & 104 & ,402 & & \\
\hline & Total & 43,664 & 106 & & & \\
\hline \multirow[t]{3}{*}{ s5NumSup } & $\begin{array}{l}\text { Between } \\
\text { Groups }\end{array}$ & 5,547 & 2 & 2,773 & $4,029 *$ & ,021 \\
\hline & $\begin{array}{l}\text { Within } \\
\text { Groups }\end{array}$ & 71,593 & 104 & ,688 & & \\
\hline & Total & 77,140 & 106 & & & \\
\hline \multirow[t]{3}{*}{ s6NumSup } & $\begin{array}{l}\text { Between } \\
\text { Groups }\end{array}$ & 1,184 & 2 &, 592 & 1,207 & ,303 \\
\hline & $\begin{array}{l}\text { Within } \\
\text { Groups }\end{array}$ & 51,022 & 104 & ,491 & & \\
\hline & Total & 52,206 & 106 & & & \\
\hline \multirow[t]{2}{*}{ s7NumSup } & $\begin{array}{l}\text { Between } \\
\text { Groups }\end{array}$ & 2,051 & 2 & 1,025 & 1,603 & ,206 \\
\hline & $\begin{array}{l}\text { Within } \\
\text { Groups }\end{array}$ & 66,510 & 104 & ,640 & & \\
\hline
\end{tabular}




\begin{tabular}{lllllll}
\hline \hline & & $\begin{array}{l}\text { Sum of } \\
\text { Squares }\end{array}$ & df & $\begin{array}{l}\text { Mean } \\
\text { Square }\end{array}$ & F & Sig. \\
\hline sotal & 68,561 & 106 & & & \\
\hline \multirow{5}{*}{ s8NumSup } & $\begin{array}{l}\text { Between } \\
\text { Groups }\end{array}$ &, 916 & 2 &, 458 & 1,328 &, 269 \\
\cline { 2 - 7 } & $\begin{array}{l}\text { Within } \\
\text { Groups }\end{array}$ & 35,851 & 104 &, 345 & & \\
\cline { 2 - 7 } & Total & 36,766 & 106 & & & \\
\hline \hline
\end{tabular}

Table 11: ANOVA for number of supportive moves

Table 11 lists the result of ANOVA for the number of supportive moves used by the participants. According to the table, there is a significant difference between the groups in situation 5.

\begin{tabular}{|c|c|c|c|c|c|}
\hline $\begin{array}{l}\text { Dependent } \\
\text { Variable }\end{array}$ & $\begin{array}{l}\text { (I) } \\
\text { Grup }\end{array}$ & (J) Grup & $\begin{array}{l}\text { Mean } \\
\text { Difference (I-J) }\end{array}$ & Std. Error & Sig. \\
\hline \multirow[t]{6}{*}{ s5NumSup } & 1 & 2 &, $517^{*}$ & , 193 & ,023 \\
\hline & & 3 & ,391 & ,195 &, 115 \\
\hline & 2 & 1 &,$- 517^{*}$ & ,193 &, 023 \\
\hline & & 3 &,- 126 & ,206 &, 814 \\
\hline & 3 & 1 &,- 391 & ,195 &, 115 \\
\hline & & 2 & , 126 & ,206 & ,814 \\
\hline
\end{tabular}

*. The mean difference is significant at the 0.05 level.

Table 12: Post-hoc tests for number of supportive moves

According to table 12, group 1 used more supportive moves in situation 5 than group 2 and there was no significant difference between group 2 and 3 . 


\begin{tabular}{|c|c|c|c|c|c|c|}
\hline & & $\begin{array}{l}\text { Sum of } \\
\text { Squares }\end{array}$ & df & $\begin{array}{l}\text { Mean } \\
\text { Square }\end{array}$ & $\mathrm{F}$ & Sig. \\
\hline \multirow[t]{3}{*}{ s1NumDown } & $\begin{array}{l}\text { Between } \\
\text { Groups }\end{array}$ & 3,579 & 2 & 1,790 & \multirow[t]{3}{*}{$3,557 *$} & \multirow[t]{3}{*}{032} \\
\hline & $\begin{array}{l}\text { Within } \\
\text { Groups }\end{array}$ & 52,327 & 104 &, 503 & & \\
\hline & Total & 55,907 & 106 & & & \\
\hline \multirow[t]{3}{*}{ s2NumDown } & $\begin{array}{l}\text { Between } \\
\text { Groups }\end{array}$ & 1,376 & 2 & ,688 & \multirow[t]{3}{*}{,790 } & \multirow[t]{3}{*}{,457 } \\
\hline & $\begin{array}{l}\text { Within } \\
\text { Groups }\end{array}$ & 90,624 & 104 & ,871 & & \\
\hline & Total & 92,000 & 106 & & & \\
\hline \multirow[t]{3}{*}{ s3NumDown } & $\begin{array}{l}\text { Between } \\
\text { Groups }\end{array}$ & 5,045 & 2 & 2,523 & \multirow[t]{3}{*}{$4,965^{*}$} & \multirow[t]{3}{*}{009} \\
\hline & $\begin{array}{l}\text { Within } \\
\text { Groups }\end{array}$ & 52,843 & 104 & ,508 & & \\
\hline & Total & 57,888 & 106 & & & \\
\hline \multirow[t]{3}{*}{ s4NumDown } & $\begin{array}{l}\text { Between } \\
\text { Groups }\end{array}$ & 2,590 & 2 & 1,295 & \multirow[t]{3}{*}{1,782} & \multirow[t]{3}{*}{, 173} \\
\hline & $\begin{array}{l}\text { Within } \\
\text { Groups }\end{array}$ & 75,578 & 104 & ,727 & & \\
\hline & Total & 78,168 & 106 & & & \\
\hline \multirow[t]{3}{*}{ s5NumDown } & $\begin{array}{l}\text { Between } \\
\text { Groups }\end{array}$ & 7,424 & 2 & 3,712 & \multirow[t]{3}{*}{$6,434 *$} & \multirow[t]{3}{*}{,002 } \\
\hline & $\begin{array}{l}\text { Within } \\
\text { Groups }\end{array}$ & 59,997 & 104 & ,577 & & \\
\hline & Total & 67,421 & 106 & & & \\
\hline \multirow[t]{3}{*}{ s6NumDown } & $\begin{array}{l}\text { Between } \\
\text { Groups }\end{array}$ & ,086 & 2 &, 043 & \multirow[t]{3}{*}{,073 } & \multirow[t]{3}{*}{,930 } \\
\hline & $\begin{array}{l}\text { Within } \\
\text { Groups }\end{array}$ & 61,055 & 104 &, 587 & & \\
\hline & Total & 61,140 & 106 & & & \\
\hline \multirow[t]{2}{*}{ s7NumDown } & $\begin{array}{l}\text { Between } \\
\text { Groups }\end{array}$ & 5,547 & 2 & 2,773 & \multirow[t]{2}{*}{$3,451 *$} & \multirow[t]{2}{*}{035} \\
\hline & $\begin{array}{l}\text { Within } \\
\text { Groups }\end{array}$ & 83,593 & 104 & ,804 & & \\
\hline
\end{tabular}




\begin{tabular}{lllllll}
\hline \hline & & $\begin{array}{l}\text { Sum of } \\
\text { Squares }\end{array}$ & df & $\begin{array}{l}\text { Mean } \\
\text { Square }\end{array}$ & F & Sig. \\
\hline s8NumDown & 89,140 & 106 & & & \\
\hline & $\begin{array}{l}\text { Between } \\
\text { Groups } \\
\text { Within } \\
\text { Groups } \\
\text { Total }\end{array}$ & 3,021 & 2 & 1,511 & 2,398 &, 096 \\
\hline \hline
\end{tabular}

Table 13: ANOVA for number of downgraders

Table 13 shows the result of ANOVA for the number of downgraders. According to the table, there is a significant difference between the groups in situation 1, 3, 5, and 7 in terms of the number of downgraders they employed in their requests.

\begin{tabular}{lllllc}
\hline \hline \multirow{2}{*}{$\begin{array}{l}\text { Dependent } \\
\text { Variable }\end{array}$} & Grup & (J) Grup & Difference (I-J) & Std. Error & Sig. \\
\hline s1NumDown & 1 & 2 &, 071 &, 165 &, 902 \\
& & 3 &, $426^{*}$ &, 166 &, 032 \\
\cline { 2 - 6 } & 2 & 1 &,- 071 &, 165 &, 902 \\
& & 3 &, 354 &, 176 &, 114 \\
\cline { 2 - 6 } & 3 & 1 &,$- 426^{*}$ &, 166 &, 032 \\
& & 2 &,- 354 &, 176 &, 114 \\
\hline s3NumDown & 1 & 2 &, 383 &, 166 &, 059 \\
& & 3 &, $491^{*}$ &, 167 &, 011 \\
\cline { 2 - 6 } & 2 & 1 &,- 383 &, 166 &, 059 \\
& & 3 &, 108 &, 177 &, 815 \\
\cline { 2 - 6 } & 3 & 1 &,$- 491^{*}$ &, 167 &, 011 \\
& & 2 &, 572 & 1,669 &, 937 \\
\hline s5NumDown & 1 & 2 &, $587^{*}$ &, 177 &, 004 \\
& & 3 &, 040 &, 178 &, 972 \\
\cline { 2 - 6 } & 2 & 1 &,$- 587^{*}$ &, 177 &, 004 \\
& & 3 &,$- 546^{*}$ &, 188 &, 013 \\
\hline
\end{tabular}




\begin{tabular}{lccccc}
\hline & 3 & 1 &,- 040 &, 178 &, 972 \\
& & 2 &, $546^{*}$ &, 188 &, 013 \\
\hline s7NumDown & 1 & 2 &, $517^{*}$ &, 209 &, 039 \\
& & 3 &, 391 &, 210 &, 155 \\
\cline { 2 - 6 } & 2 & 1 &,$- 517^{*}$ &, 209 &, 039 \\
& 3 &,- 126 &, 222 &, 838 \\
\cline { 2 - 6 } & 3 & 1 &,- 391 &, 210 &, 155 \\
& 2 &, 126 &, 222 &, 838 \\
\hline \hline
\end{tabular}

*. The mean difference is significant at the 0.05 level.

Table 14: Post-hoc tests for number of downgraders

Table 14 show that in situation 1 group 1 used more downgraders than group 3 and there was no significant difference between group 2 and 3. Again, in situation 3, group I used more downgraders than group 3 and there was no difference between the group 2 and 3 . In situation 5, group 1 and group 3 used more downgraders than group 2. In situation 7 , group 1 used more strategies than group 2 and there was no difference between group 2 and 3.

\begin{tabular}{|c|c|c|c|c|c|c|c|c|}
\hline \multicolumn{9}{|c|}{ Probability Values } \\
\hline & Sit. 1 & Sit. 2 & Sit. 3 & Sit. 4 & Sit. 5 & Sit. 6 & Sit. 7 & Sit. 8 \\
\hline Power & + & + & + & + & - & - & - & - \\
\hline Distance & + & + & - & - & + & + & - & - \\
\hline Imposition & + & - & + & - & + & - & + & - \\
\hline Length & $.016^{*}$ & .287 & .682 & .580 & $.018^{*}$ & .539 & $.026^{*}$ & .980 \\
\hline Head Act & .654 & .065 & .374 & .757 & .127 & .465 & .326 & 1.0 \\
\hline $\begin{array}{l}\text { Supportive } \\
\text { Move }\end{array}$ & .536 & .091 & .756 & .103 & $.021 *$ & .303 & .206 & .269 \\
\hline Downgrader & $.032 *$ & .457 & $.009 *$ & .173 & $.002 *$ & .930 & $.035 *$ & .096 \\
\hline
\end{tabular}

Table 15: Summary of probability values in ANOVA tests.

As table 15 indicates, the differences that occurred only occurred in situation 1 , situation 3 , situation 5 and situation 7 . What is common among these situations is that in these situations the imposition of the request on the hearer is high. In other situations in which 
no differences occurred, the imposition is low. Another finding is that except for one case where there is a significant difference between group 2 and 3 (namely the number of downgraders in situation 5), the differences were either between group 1 and group 2 or group 1 and group 3.

\section{Conclusion}

Results show that receiving education in another language, in this case English, does not seem to have an effect of the selection of strategies. However, the results do show that the make-up of requests such as the length or the number of strategies employed seem to be affected by the language of education. One of the most interesting findings of this study is that the differences only occurred in situations with high impositions. This tells us that receiving education in another language seems to affect sociopragmatic interpretation in the native language. Students who received their education in English used longer requests and more strategies in situations with high imposition than those who received their education in their native language, Turkish. This shows that students who received their education in English interpreted the situations with high imposition differently from the other groups and tended to use longer requests with more strategies. This was not the case in situation with low imposition. The findings of this study are significant because if receiving education in another language has an impact on students' first languages, different types of native speakers of a language will emerge and such differences in the native language will result in the question of "native speakerness". Thus, before making a decision of offering a program in another language, possible advantages, shortcomings and outputs should be carefully critiqued. We may be doing harm with the intention of doing good.

\section{References}

Airey, J. (2004) Can you teach it in English? Aspects of the language choice debate in Swedish higher education. Retrieved 14 September 2010 from the World Wide Web: http://www.hik.se/dokument/.\%5Chumsam\%5Cengelska\%5Cjaresearch/langchoice.pdf

Al-Eryani, Abdullah A. 2007. "Refusal Strategies by Yemeni EFL learners." The Asian EFL Journal Quarterly 9 (2): 19-34.

Blum-Kulka, Shoshana, House, Juliane and Kasper, Gabriele (eds.). 1989. CrossCultural Pragmatics: Requests and Apologies. Norwood, NJ: Ablex.

Blum-Kulka, Shoshana and Sheffer, Hadass. 1993. "The Metapragmatic Discourse of American-Israeli Families at Dinner." In Interlanguage Pragmatics, Kasper, Gabriele and Blum-Kulka, Shoshana (eds.),196-223. Oxford: Oxford Univesity Press.

Brown, Penelope and Levinson, Stephen. 1987. Politeness: Some Universals in Language Usage. Cambridge: Cambridge University Press.

Chang, Yuh-Fang. 2009. "How to say no: an analysis of cross-cultural difference and pragmatic transfer." Language Sciences 31: 477-493. 
Cenoz, Jasone. 2003. "The intercultural style hypothesis: L1 and L2 interaction in requesting behaviour." In Effects of the second language on the first, Vivian Cook (ed.), 62-80. Clevedon: Multilingual Matters.

Coleman, James A. 2006. "English-medium teaching in European higher education." Language Teaching 39: 1-14.

Cook, Vivian. 2003. "Introduction: The changing L1 in the L2 user's mind." In Effects of the second language on the first, Vivian Cook (ed.), 1-18. Clevedon: Multilingual Matters.

Crystal, David. 2003. English as a global language. New York: Cambridge University Press.

Gass, Susan. 1979. "Language transfer and universal grammatical relations." Language Learning 29 (2): 327-344.

Graddol, David. 2000. The future of English? London: The British Council.

Hassall, Tim. 2003. "Requests by Australian learners of Indonesian." Journal of Pragmatics 35: 1903-1928

Hudson, Thom, Detmer, Emily and Brown, James D. 1995. Developing prototypic measures of cross-cultural pragmatics. Technical report \# 7 . Honolulu, HI: University of Hawai'i Press.

Jarvis, Scott. 2003. "Probing the effects of the L2 on the L1: A case study." In Effects of the Second Language on the First, Vivian Cook (ed.), 120-141. Clevedon: Multilingual Matters.

Jarvis, Scott and Odlin, Terence. 2000. "Morphological type, spatial reference, and language transfer." SSLA 22: 535-556.

Jia, Yuxin. 2007. "Pragmatic diversity, pragmatic transfer, and cultural identity." Intercultural Communication Studies 16 (2): 37-54.

Kecskes, Istvan and Papp, Tunde. 2003. "How to demonstrate the conceptual effect of L2 on L1? Methods and techniques." In Effects of the Second Language on the First, Vivian Cook (ed.), 247-265. Clevedon: Multilingual Matters.

Kecskes, Itsvan. 2000. "Conceptual fluency and the use of situation-bound utterances in L2.” Links \& Letters 7: 145-161.

Lado, Robert. 1957. Linguistics across Cultures. Applied Linguistics for Languag Teachers. Ann Arbor: The University of Michigan Press.

Pavlenko, Aneta and Jarvis, Scott. 2002. "Bidirectional transfer." Applied Linguistics 23 (2): 190-214.

Qu, Jing and Wang, Liying. (2005). Pragmatic transfer in compliment responses by Chinese learners of English. Sino-US English Teaching, 2, 12, 66-75.

Rose, Kenneth R. 2000. "An exploratory cross-sectional study of interlanguage pragmatic development." SSLA 22: 27-67.

Sasaki, T. and Beamer, M. S. 2002. "Pragmatic transfer and length of residence in a target language". In JALT2002 Conference Proceedings, M.Swanson and K. Hill (eds.), 379-388. Tokyo: The Japan Association of Language Teaching.

Seidlhofer, Barbara. 2005. "Key concepts in ELT English as a lingua franca." ELT Journal 59 (4): 339-341.

Selinker, Larry. 1972 "Interlanguage" IRAL; International Review of Applied Linguistics in Language Teaching 10 (3): 209-231 
Silva, Rosangela S. 2000. "Pragmatics, bilingualism, and the native speaker." Language \& Communication 20: 161-178.

Tran, Giao Q. 2007. "The nature of pragmatic and discourse transfer in compliment responses in cross-cultural interaction". The Linguistics Journal 3 (3): 167-205.

Wannaruk, Anchalae. 2008. "Pragmatic transfer in Thai EFL refusals". RELC Journal 39: 318-337.

\begin{abstract}
About the Author
Mehmet Kanik received his BA in Foreign Language Education from Middle East Technical University in 2000 and his MS in TESOL from the University of Southern California in 2003. Next, he took graduate courses at the University of Arizona between 2003 and 2005. In 2010, he finished his PhD in English Language Teaching at Istanbul University. He is currently working at the University of Houston as a visiting assistant professor as well as visiting Texas A\&M University as a visiting scholar. Some of his research interests are cross-cultural pragmatics, speech acts, cross-linguistic influence and English as a lingua franca.
\end{abstract}

